\title{
PEMBERIAN MINYAK IKAN LELE (Clarias gariepinus) TERHADAP BOBOT BADAN DAN PERUBAHAN HISTOPATOLOGI HATI, GINJAL, DAN OTAK TIKUS GALUR Sprague dawley YANG DIBERI PAKAN HIPERKOLESTEROLEMIA
}

\section{(The effect of catfish [Clarias gariepinus] oil intervention to weight gain and histopathology liver, kidney and brain changes of Sprague dawley rats fed hypercholesterolemia diets)}

\author{
Hardi Firmansyah ${ }^{1}$, Katrin Roosita ${ }^{1}$, Clara Meliyanti Kusharto ${ }^{1 *}$, Ekowati Handharyani ${ }^{2}$ \\ ${ }^{1}$ Departemen Gizi Masyarakat, Fakultas Ekologi Manusia (FEMA), Institut Pertanian Bogor, Bogor 16680 \\ ${ }^{2}$ Departemen Klinik Reproduksi Patologi, Fakultas Kedokteran Hewan, Institut Pertanian Bogor, Bogor \\ 16680
}

\begin{abstract}
The objective of this study was to analyze changes in body weight and cell morphology in liver, kidney and brain tissue of Sprague dawley rats administered hypercholesterolemia diets for four weeks. Four diet treatments were applied in this study: control, catfish oil, catfish oil with the addition of omega 3 and catfish oil with the addition of omega 3 and vitamin E. Four weeks after the intervention, the rats were sacrificed and the internal organs (liver, brain, and kidney) were taken for histological preparations by hematoxylin-eosin (HE) and immunohistochemistry test. The study showed that the catfish oil intervention tend to reduced weight gain of rats fed hypercholesterolemia diets. More lipid accumulation in liver of the control group was found than the intervention groups. However, there was no difference in the histopathology of the kidney and brain tissues between the control group and intervention groups. It is concluded that catfish oil study provides a positive effect in rat liver tissue, but no difference exists between the brain and kidney tissue. There is no defect found at hippocampus of rats by formed of amyloid plague.
\end{abstract}

Keywords: brain, catfish oil, histopathology, kidney, liver

\begin{abstract}
ABSTRAK
Tujuan penelitian ini adalah menganalisis perubahan bobot badan dan morfologi sel di hati, ginjal dan otak tikus Sprague dawley yang diberi pakan hiperkolesterolemia selama empat minggu. Penelitian ini terdiri atas empat perlakuan yaitu kontrol, minyak ikan lele, minyak ikan lele dengan penambahan omega 3 serta minyak ikan lele dengan penambahan omega 3 dan vitamin E. Empat minggu setelah intervensi, tikus-tikus dimatikan, kemudian hati, ginjal dan otak diambil untuk persiapan histologis dengan metode hematoksilin eosin (HE) dan imunohistokimia. hasil penelitian menunjukkan bahwa pemberian minyak ikan lele pada tikus yang diberi pakan hiperkolesterolemia cenderung menekan kenaikan bobot badan. Akumulasi lipid lebih banyak ditemukan pada hati tikus kelompok kontrol dibandingkan kelompok intervensi yang diberikan minyak ikan lele, namun tidak ada perbedaan antara kelompok kontrol dan kelompok intervensi pada ginjal dan jaringan otak. Hal ini menunjukkan bahwa minyak ikan lele memberikan efek positif pada jaringan hati tikus, namun tidak ada perbedaan pada jaringan ginjal dan otak. Plak amiloid belum terbentuk pada hipokampus otak tikus.
\end{abstract}

Kata kunci: ginjal, hati, histopatologi, minyak ikan lele, otak

\section{PENDAHULUAN}

Penyakit Alzheimer (PA) merupakan sindrom dengan apoptosis (kematian) sel-sel otak yang terjadi dalam waktu yang bersamaan. Penderita sindrom ini pada umumnya merupakan individu yang berusia lanjut (60 tahun ke atas). Tanda-tanda PA biasanya berupa hilangnya neuron, cairan ektraseluler yang mengandung pep- tida amiloid $\beta(\mathrm{A} \beta)$ dan kusutnya neurofibril serta terjadinya hiperfosforilasi dari mikrotubular TAU protein. Penyebab terjadinya PA adalah munculnya plak amiloid dan neuro tangled pada neurofibril. Beberapa studi yang mempelajari oksidasi dan inflamasi pada proses PA, terdapat fakta bahwa gangguan pada metabolisme lipid juga berperan. Individu yang mengalami PA akan mengalami kepikunan, kehilangan kemampuan

\footnotetext{
"Korespondensi: Telp: +622518624907, Surel: kcl_51@yahoo.co.id
} 
berbahasa, penurunan fungsi kognitif, kelainan psikososial, halusinasi, bahkan kehilangan kendali pada tubuh, dan emosional (Reitz et al. 2011; Kolorev 2014; Alzheimer's Association 2017).

Salah satu faktor risiko individu menderita PA adalah tingginya konsumsi lemak pada diet harian (Reitz et al. 2011). Individu yang mengonsumsi diet tinggi lemak selama tiga sampai empat dekade terakhir memiliki peningkatan yang signifikan terhadap risiko PA dimasa tua (Cooper 2003). Penelitian Davidson et al. (2010) menunjukkan bahwa tikus yang diberi diet tinggi lemak dapat menimbulkan risiko disfungsi saraf. Granholm et al. (2008) menjelaskan bahwa konsumsi pakan tinggi kolesterol selama delapan minggu mampu merusak morfologi hipokampus tikus. Hal ini diperkuat dengan penelitian Freeman \& Granholm (2012) yang menemukan bahwa terdapat banyak respons imunitas pada hipokampus tikus yang diberi pakan tinggi lemak selama enam bulan.

Bahan yang dapat mengurangi kadar kolesterol dalam darah diantaranya adalah minyak ikan. Minyak ikan merupakan produk turunan dari ikan yang dihasilkan dari proses ektraksi tepung ikan atau pengalengan ikan, yang dapat diproduksi baik dari ikan air laut maupun ikan air tawar serta memiliki manfaat kesehatan dan gizi (Irianto \& Soesilo 2007). Minyak ikan diketahui mengandung omega 3 dan omega 6 yang bermanfaat bagi kesehatan jika dikonsumsi sebagai suplemen (Minis et al. 2006). Beberapa penelitian menunjukkan bahwa omega 3 dapat menurunkan kadar trigliserida, meningkatkan High Density Lipoprotein (HDL) dan menurunkan kadar Low Density Lipoprotein (LDL) (Covington 2004); mengurangi risiko kerusakan dan penurunan kemampuan kognitif pada lansia (Gonzales et al. 2010); meredakan reaksi inflamasi dan mengurangi tingkat komplikasi inflamasi (Wei et al. 2014). Cooper (2003) mengatakan bahwa hal ini disebabkan lemak tak jenuh seperti omega 3 diperkirakan memiliki sifat melindungi (protektif) sel saraf dari risiko PA.

Minyak ikan lele merupakan hasil samping dari proses pembuatan tepung ikan lele. Minyak ikan lele diketahui memiliki 12,37\% omega 6 dan 1,31\% omega 3 (Srimiati et al. 2015). Penelitian Dainy et al. (2016) menemukan bahwa minyak ikan lele yang ditambah omega 3 dapat menurunkan nilai trigliserida secara signifikan dan cenderung meningkatkan kadar HDL. Sejauh ini belum cukup diperoleh informasi ilmiah mengenai pengaruh konsumsi minyak ikan lele murni (tanpa penambahan omega 3 ) terhadap berat badan dan plak amiloid pada lansia. Minyak ikan lele pada penelitian ini selain menggunakan minyak ikan lele murni, juga menggunakan minyak ikan lele yang ditambah omega 3 dan vita- min E. Omega 3 ditambah untuk menyeimbangkan rasio omega 3 dan omega 6 dalam minyak ikan lele, sedangkan vitamin E berfungsi untuk memperpanjang masa simpan minyak ikan lele.

Tikus merupakan hewan rodensia yang banyak digunakan sebagai hewan coba dalam penelitian karena memiliki kesamaan dengan manusia dalam sistem reproduksi, sistem saraf, dan penyakit serta mudah, murah, dan banyak tersedia (Zarafoza et al. 2011). Pakan hiperkolesterolemia merupakan pakan yang sengaja dibuat untuk meningkatkan kadar kolesterol darah hewan coba (Hardiningsih \& Nurhidayat 2005; Astuti 2015). Pakan hiperkolesterolemia dapat menyebabkan perlemakan hati pada tikus (Krisnansari et al. 2014). Selain itu Noeman et al. (2011) menyebutkan bahwa obesitas yang dipicu diet tinggi lemak dapat memengaruhi organ hati, ginjal, jantung dan otak.

Berdasarkan uraian tersebut, penelitian ini dilakukan dengan tujuan untuk menguji efek dari pemberian minyak ikan lele terhadap perubahan bobot badan serta histopatologi hati, ginjal, dan otak tikus Sprague dawley yang diberi pakan hiperkolesterolemia.

\section{METODE}

\section{Desain, tempat, dan waktu}

Penelitian dilakukan secara eksperimental menggunakan desain Randomized Controlled Trial (RCT). Rancangan percobaan yang digunakan adalah Rancangan Acak Lengkap (RAL) dengan empat perlakuan yaitu kontrol, minyak ikan lele, minyak ikan lele dengan penambahan omega 3, serta minyak ikan lele dengan penambahan omega 3 dan vitamin E. Penelitian dilakukan pada bulan Juli-September 2015 yang merupakan bagian dari Penelitian Unggulan Perguruan Tinggi (PUPT) tahun 2015 yang berjudul minyak ikan lele (Clarias gariepinus) sebagai suplemen alternatif pencegah alzheimer pada lansia. Tikus dipelihara di Unit Pengelola Hewan Laboratorium (UPHL) Fakultas Kedokteran Hewan (FKH), Institut Pertanian Bogor. Pelaksanaan nekropsi, pembuatan preparat serta analisis histopatologi dilakukan di Laboratorium Patologi Fakultas Kedokteran Hewan IPB.

\section{Jumlah dan cara pengambilan sampel}

Hewan coba yang digunakan dalam penelitian ini adalah tikus jantan Sprague dawley berumur 6-8 bulan dengan berat 400-500 g yang diperoleh dari Fakultas Kedokteran Hewan, Institut Pertanian Bogor yang telah memperoleh persetujuan atas perlakuan etik dari Komisi Etik Hewan LPPM IPB No 09A-2015 IPB. Tikus sebanyak 24 ekor dibagi menjadi 4 kelompok perlakuan yaitu kelompok kontrol (A1), kelompok intervensi 
minyak ikan lele tanpa penambahan konsentrat minyak omega 3 (A2), kelompok intervensi minyak ikan lele dengan penambahan konsentrat minyak omega 3 (A3) serta kelompok intervensi minyak ikan lele dengan penambahan omega 3 dan vitamin E (A4).

\section{Bahan dan alat}

Bahan yang digunakan adalah tikus jantan galur Sprague dawley, kloroform, minyak ikan lele (Clarias gariepinus), citrate buffer, phosphate buffered saline, $\mathrm{H}_{2} \mathrm{O}_{2}$, larutan biotin, streptavidin, diaminobenzidine, air, entelan, omega 3 (K-omegaSqua Plus, PT K-Link Indonesia), vitamin E (DL- $\alpha$-tocopherol acetate, Sigma Aldrich, Singapura), pakan standar, dan pakan tinggi kolesterol. Alat yang digunakan dalam penelitian ini adalah set kandang perlakuan, surgery set, kaca objek, kaca penutup (cover glass), mikroskop cahaya, kamera, alat sonde, timbangan, dan kit pewarnaan imunohistokimia.

\section{Tahapan penelitian}

Tikus terlebih dahulu diberikan pakan hiperkolesterolemia sebanyak $30 \mathrm{~g}$ untuk menaikkan kadar kolesterol dalam darah. Bahan dari pakan ini adalah tepung ikan (8\%), bungkil kedelai (20\%), minyak kelapa $(6 \%), \mathrm{CaCO}_{3}(1 \%)$, garam (1\%), tepung jagung $(60 \%)$, kuning telur (3\%), mineral premix (1\%). dan air (Astuti 2015).

Pakan hiperkolesterolemia yang digunakan pada penelitian ini mengandung kolesterol sebesar $0,154 \mathrm{mg} / \mathrm{g}$ (Astuti 2015) serta karbohidrat sebesar $60,59 \%$, protein $17,08 \%$, lemak $7,35 \%$, kadar air $9,87 \%$, kadar abu 5,45\% dan kadar serat kasar 3,66\%. Pakan standar mengandung protein kasar $23 \%$, lemak $4 \%$, dan kadar abu 8\%. Pakan hiperkolesterolemia diberikan selama 2 minggu kepada semua tikus untuk meningkatkan kadar kolesterol darah tikus (Gani et al. 2013). Hasil penelitian Laksitoresmi et al. (2016) yang menggunakan tikus yang sama menunjukkan bahwa setelah dua minggu pemberian pakan hiperkolesterolemia, tikus mengalami hiperkolesterolemia. Kadar kolesterol total sebesar 77,0 $\pm 9,9 \mathrm{mg} / \mathrm{dl}$ dimana kadar kolesterol total tikus normal sebesar 10-45 mg/dl (Harini \& Okid 2009), kadar trigliserida sebesar $139,0 \pm 67,9 \mathrm{mg} /$ dl dimana kadar trigliserida darah tikus normal sebesar 32,94-70,79 mg/dl (Ihedioha et al. 2013), kadar HDL sebesar 33,5 $\pm 4,9 \mathrm{mg} / \mathrm{dl}$ lebih rendah dibanding kadar normal sebesar 39,02-72,20 mg/ dl (Ihedioha et al. 2013), sedangkan kadar LDL sebesar $14,5 \pm 2,1 \mathrm{mg} / \mathrm{dl}$ masih dalam batas normal diantara 2,39-27,34 mg/dl (Ihedioha et al. 2013). Intervensi dilanjutkan dengan pemberian minyak ikan lele kepada tikus kelompok intervensi A2, A3, dan A4 secara oral dalam bentuk cairan dengan alat sonde selama dua minggu berikutnya (Wood et al. 2010). Minyak ikan lele yang diberikan sebanyak $0,8 \mathrm{ml}$ per ekor per hari (Mona 2014). Bobot badan tikus ditimbang setiap minggu. Minyak ikan lele yang digunakan dalam penelitian ini adalah minyak ikan yang sama dengan penelitian Kusharto et al. (2015) dan Laksitoresmi et al. (2016) yang menggunakan metode Srimiati et al. (2015).

Hari ke-15 setelah pemberian minyak ikan lele berbagai perlakuan, hewan coba dibius dengan menggunakan ketamin dan dilakukan pembedahan untuk mengambil organ hati, ginjal, dan otak besar. Organ tersebut kemudian dibuat preparat histologisnya dan dilakukan analisis pada tampilan jaringan organ yang menggunakan mikroskop dengan pembesaran $10 \mathrm{x} 40$. Tampakan plak beta amiloid pada jaringan otak dianalisis menggunakan pewarnaan imunohistokimia (Wresdiyati et al. 2015), sedangkan perubahan sel pada otak, ginjal, dan hati menggunakan metode perwarnaan hematoksilin eosin (HE).

\section{Pengolahan dan analisis data}

Data perubahan bobot tikus dianalisis menggunakan analisis paired t-test untuk perbedaan pada awal dan akhir intervensi serta analisis sidik ragam untuk perbedaan antar kelompok perlakuan. Pengamatan yang dilakukan terhadap preparat yang dihasilkan menggunakan mikroskop dengan pembesaran $10 \times 40$. Data yang dihasilkan diolah dengan cara deskriptif (memperhatikan gambaran histopatologis jaringan).

\section{HASIL DAN PEMBAHASAN}

\section{Perubahan bobot tikus}

Tikus diberikan pakan tinggi kolesterol dan ditimbang bobot badannya selama empat minggu. Selama intervensi, hanya seekor tikus yang mati yakni tikus perlakuan A3. Gambar 1 menunjukkan bahwa bobot tikus mengalami peningkatan setelah diberikan pakan hiperkolesterolemia selama dua minggu pertama. Hal ini sesuai dengan penelitian yang dilakukan Nikasa et al. (2016) yang menunjukkan bahwa diet tinggi kolesterol secara signifikan meningkatkan bobot badan tikus. Beberapa penelitian serupa menunjukkan bahwa tikus yang diberikan pakan tinggi lemak bobot badannya akan meningkat secara signifikan (Davidson et al. 2010; Chien et al. 2016; Marques et al. 2016). Pada minggu ketiga dan keempat mulai diberikan intervensi berdasarkan kelompok perlakuan. Gambar 1 menunjukkan bahwa pada minggu ketiga dan keempat kelompok yang diberikan minyak ikan lele (A2 dan A3) cenderung mengalami penurunan bobot badan dan A4 mengalami peningkatan lebih rendah dibandingkan kelompok kontrol (A1). 
Firmansyah dkk.

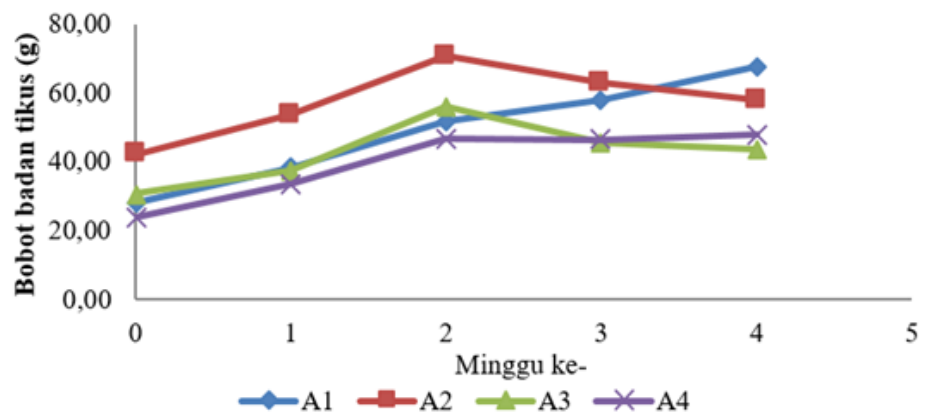

Gambar 1. Grafik peningkatan bobot badan tikus per minggu

Tabel 1. Perubahan bobot badan tikus sebelum dan sesudah intervensi

\begin{tabular}{cccccc}
\hline $\begin{array}{c}\text { Jenis } \\
\text { intervensi }\end{array}$ & $\begin{array}{c}\text { Sebelum } \\
\text { intervensi }(\mathrm{g})\end{array}$ & $\begin{array}{c}\text { Sesudah } \\
\text { intervensi }(\mathrm{g})\end{array}$ & $\begin{array}{c}\text { Perubahan } \\
\text { bobot badan }(\mathrm{g})\end{array}$ & $\mathrm{p}^{1}$ & $\mathrm{p}^{2}$ \\
\hline A1 & $382,17 \pm 55,26$ & $398,00 \pm 52,94$ & 15,83 & $0,000^{*}$ & \\
A2 & $423,00 \pm 65,91$ & $410,33 \pm 59,61$ & $-12,67$ & 0,357 & 0,090 \\
A3 & $399,50 \pm 82,09$ & $390,67 \pm 87,95$ & $-8,83$ & 0,359 & \\
A4 & $349,33 \pm 68,24$ & $350,67 \pm 59,25$ & 1,33 & 0,797 & \\
\hline
\end{tabular}

Keterangan: *signifikan pada $\alpha=0,05$; ${ }^{1}$ analisis paired $t$-test sebelum dan setelah intervensi; ${ }^{2}$ analisis ANOVA antar perlakuan.

Tabel 1 menunjukkan bahwa bobot badan tikus mengalami peningkatan yang signifikan pada kelompok kontrol $(\mathrm{p}<0,05)$, sedangkan pada kelompok A2 dan A3 bobot badan tikus cenderung mengalami penurunan namun tidak signifikan. Bobot tikus perlakuan A4 cenderung meningkat namun tidak signifikan. Hal ini diduga karena kandungan omega 3 dalam minyak ikan lele mampu menekan kenaikan berat badan. Simopoulos (2016) menyatakan bahwa omega 3 mampu menghalangi terbentuknya enzim lipogen yang berperan dalam pembentukan lemak yang akan terakumulasi pada sel adiposa. Penelitian yang dilakukan oleh Hassanali et al. (2010) menjelaskan bahwa pemberian suplemen omega 3 mampu menurunkan berat badan pada kondisi hiperkolesterolemia, sejalan dengan penelitian yang dilakukan oleh Ruzickova et al. (2004) dan Mendez-Sanchez et al. (2001). Hasil analisis ANOVA menunjukkan bahwa tidak terdapat perbedaan yang signifikan antar perlakuan.

\section{Perubahan histopatologi hati}

Pemberian pakan hiperkolesterolemia pada tikus Sprague dawley selama empat minggu menyebabkan perubahan di dalam jaringan hati (Gambar 2). Tikus yang diberi pakan hiperkolesterolemia tanpa pemberian minyak ikan lele (perlakuan A1) terjadi akumulasi lipid yang nyata di dalam sel-sel hati (hepatosit) dibandingkan dengan hepatosit tikus yang diberikan minyak ikan lele. Akumulasi lipid dalam sel hati ditunjukkan dengan munculnya vakuola lemak pada sitoplasma (Gambar 2.A1) dalam jumlah yang signifikan, dilatasi sinusoid, dan degenerasi hidropis.

Gambaran histopatologi tikus yang mendapat perlakuan A1 ditemukan akumulasi lemak/lipid. Perubahan yang terlihat berupa akumulasi lemak pada sitoplasma hepatosit, disertai degenerasi hidropik dan nekrosis. Perubahan lain yang ditemukan adalah pelebaran sinusoid. Hal ini membuktikan bahwa asupan lemak yang berlebihan dapat mengakibatkan perlemakan dan mengganggu fungsi hati. Penelitian yang dilakukan oleh Laksitoresmi et al. (2016) menunjukkan bahwa kenaikan asupan pakan kolesterol dapat menaikkan jumlah total kolesterol dalam serum darah. Penelitian tersebut juga menjelaskan bahwa kadar kolesterol total, trigliserida dan LDL pada kelompok tikus yang tidak diberi minyak ikan lele (A1) cenderung lebih tinggi daripada tikus yang diberi minyak ikan lele (A2, A3 dan A4). Nurdin et al. (2016) menyatakan bahwa akumulasi lipid pada hati tikus terjadi lebih dahulu dibandingkan perubahan profil lipid pada serum dan juga mengindikasikan bahwa penilaian akumulasi lipid pada histopatologi jaringan hati lebih sensitif untuk mengamati perbedaan hasil perlakuan pemberian minyak dengan komposisi lemak jenuh dan lemak tak jenuh yang berbeda apabila dibandingkan dengan penilaian profil lipid serum. Herpandi (2005) menunjukkan bahwa kadar kolesterol berlebihan dapat menyebabkan gangguan pada proses metabolisme lemak, sehingga terjadi kondisi hiperkolesterolemia. Pada kondisi hiperkolesterolemia, kolesterol yang masuk ke dalam hati tidak dapat diangkut seluruh- 


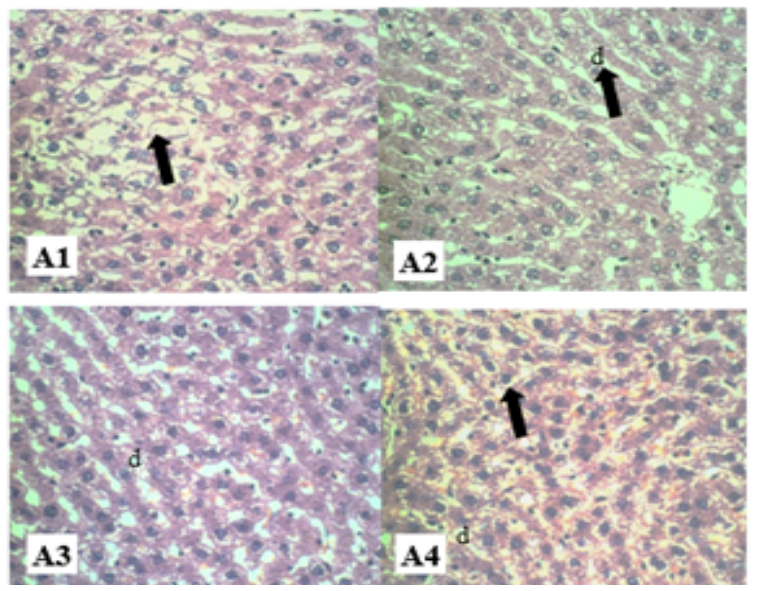

Keterangan: Tanda panah pada A1 menunjukkan akumulasi lipid yang signifikan pada sitoplasma; tanda panah pada A2 menunjukkan dilatasi sinusoid yang menyebabkan atrof; tanda panah pada A4 menunjukkan sel hepatosit mengalami degenerasi hidropik; kelompok A2, A3 dan A4 terjadi dilatasi sinusoid (d); pewarnaan Hematoksilin dan Eosin/HE, perbesaran objektif 40x.

Gambar 2. (A1) hati kelompok A1, (A2) hati kelompok (A3) kelompok hiperkolesterol+minyak ikan lele+omega 3, (A4) hati kelompok A4

nya oleh lipoprotein dari aliran darah sehingga membuat kadar total kolesterol dan LDL meningkat.

Gambaran histopatologi kelompok A2, A3, dan A4 mempunyai kemiripan yaitu vakuola lemak masih ditemukan namun dalam jumlah yang sedikit dan berukuran kecil di dalam sitoplasma sel-sel hati. Selain itu, pada kelompok A2, A3, dan A4 ditemukan pula beberapa sel hati yang mengecil (atrofi) sebagai dampak dari pelebaran sinusoid (dilatasi) (Gambar 2. A2).

Perlakuan pada A2 dan A3, masih terdapat beberapa sel hepatosit yang mengalami degenerasi pada sitoplasmanya, namun dibandingkan dengan A1, sel hepatosit A2 dan A3 cenderung mengarah menuju perbaikan. Perlakuan A4 juga mengalami perbaikan walau masih terdapat sel hepatosit yang mengalami degenerasi hidropik (Gambar 2. A4). Kemungkinan perbaikan sel ini terjadi karena kandungan minyak ikan lele yang dapat memberikan pengaruh positif pada hepatosit. Srimiati et al. (2015) mengatakan bahwa minyak ikan lele mengandung omega 6 dan omega 3 walaupun perbandingan omega 6 lebih tinggi dari omega 3. Hal ini sesuai dengan pernyataan Chen et al. (2016) yang menyatakan bahwa pemberian omega 3 dapat meningkatkan steatosis hati dan memperbaiki fungsi hati.

\section{Perubahan histopatologi ginjal}

Gambar histopatologi ginjal tiap perlakuan dapat dilihat di Gambar 3. Kondisi glomerulus dan tubulus yang terdapat pada jaringan ginjal kelompok A1 tidak mengalami perubahan akibat pemberian pakan hiperkolesterolemia. Hal ini memperlihatkan bahwa intervensi yang diberikan tidak menyebabkan perubahan pada struktur ginjal. Hasil pemeriksaan histopatologi dapat dijelaskan bahwa tidak terdapat perbedaan secara mikroskopik antara perlakuan A1, A2, A3, dan A4.

Sel yang terdapat pada ginjal tiap perlakuan tampak tidak menunjukkan perubahan yang mengarah pada kerusakan dan malfungsi dari ginjal. Hal ini diduga karena kadar LDL darah tikus tiap perlakuan masih berada dalam kadar normal setelah 4 minggu pemberian pakan hiperkolesterolemia yaitu berkisar antara 9,67 $\pm 4,07$ sam-

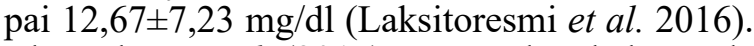
Bhagaskara et al. (2015) menyatakan bahwa ada hubungan erat antara kadar LDL dalam darah dengan kadar ureum dan kreatinin dalam urin pasien ginjal kronik. Penelitian Wresdiyati et al.

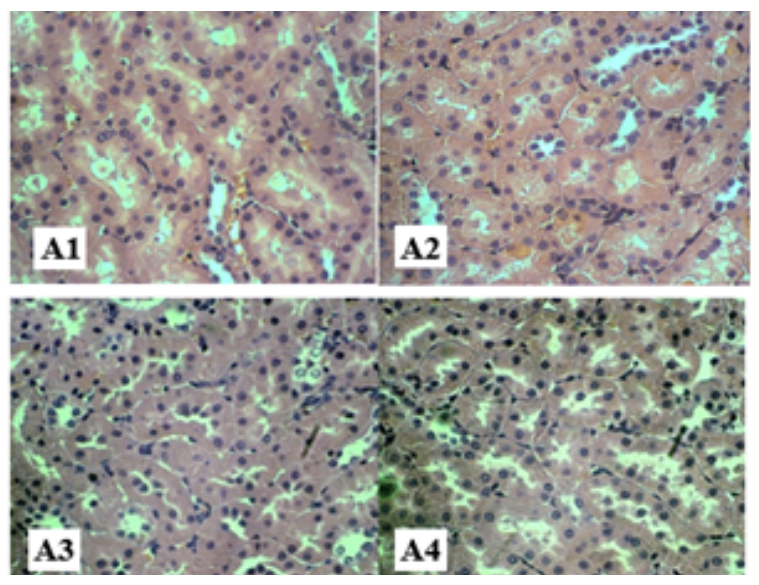

Keterangan: Pewarnaan HE, objektif 40x.

Gambar 3. ginjal kelompok A1; ginjal kelompok A2; ginjal kelompok A3; dan ginjal kelompok A4

(2011) menunjukkan bahwa ketika nilai kolesterol total mendekati normal maka jaringan ginjal mengalami perbaikan. Hal ini menunjukkan bahwa meningkatnya kadar lipid dalam darah, dapat berisiko tinggi terhadap fungsi organ ginjal.

\section{Perubahan histopatologi otak}

Gambar 4 menunjukkan bahwa tidak terdapat perbedaan gambaran histopatologi pada struktur sel neuron penyusun hipokampus baik pada perlakuan A1, A2, A3, dan A4. Hal ini menunjukkan bahwa asupan lemak yang berasal dari pakan yang diberikan selama empat minggu tidak berpengaruh pada struktur sel neuron hipokampus.

Hasil penelitian ini berbeda dengan hasil penelitian Granholm et al. (2008) yang memperlihatkan bahwa asupan asam lemak jenuh, koles- 


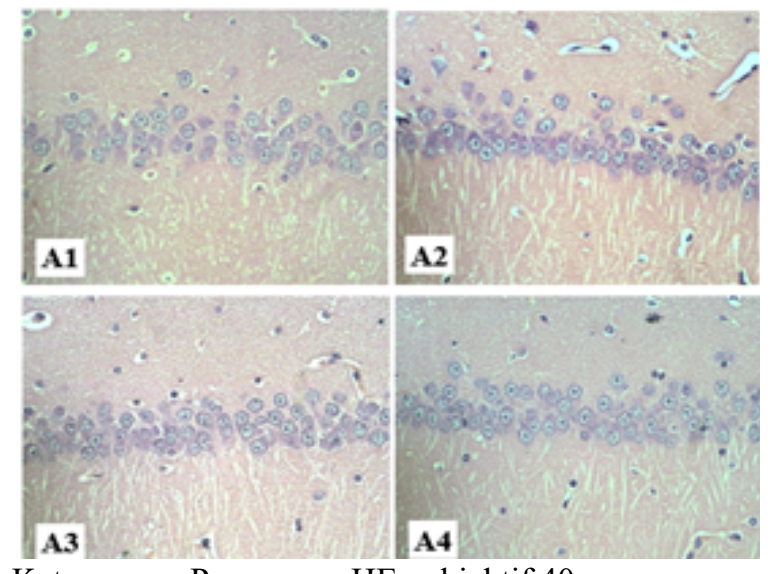

Keterangan: Pewarnaan HE, objektif 40x.

Gambar 4. (A1) hipokampus kelompok kontrol, (A2) hipokampus kelompok pemberian minyak ikan lele murni (A3), hipokampus kelompok pemberian minyak ikan lele+ omega 3, (A4) hipokampus kelompok pemberian minyak ikan lele+ vitamin E.

terol dan lemak terhidrogenasi selama delapan minggu dapat merusak kemampuan memori dan morfologi hipokampus pada tikus. Perbedaan hasil ini kemungkinan disebabkan jangka waktu intervensi yang singkat (4 minggu) sehingga belum muncul kerusakan yang berarti pada sel hipokampus.

\section{Beta amiloid pada jaringan otak}

Hasil pewarnaan imunohistokimia pada jaringan otak yang diamati di bagian hipokampus tidak terlihat plak beta amiloid pada semua perlakuan (A1, A2, A3 dan A4). Hal ini diperkirakan karena waktu penelitian ini hanya empat minggu sehingga kemungkinan proses terbentuknya plak beta amiloid belum terjadi. Arsenault et al. (2012) menyatakan bahwa pengaruh pemberian diet tinggi omega 3 dan asam lemak tidak jenuh akan terlihat apabila waktu penelitian dilakukan selama 9-13 bulan (36-52 minggu). Hal ini terkait dengan perbandingan rasio konsumsi pangan rendah omega 3 dan omega 6 yang dapat meningkatkan protein tau yang tidak dapat dibuang tubuh pada tikus intervensi.

Hal ini juga sesuai dengan Phivilay et al. (2010) yang mengatakan bahwa pemberian 6-12 bulan asam lemak trans kepada tikus model alzheimer dapat mengubah profil asam lemak yang terdapat di otak. Penelitian Julien et al. (2010) menyatakan bahwa konsumsi diet tinggi lemak dengan rasio PUFA omega 6 dan omega 3 yang rendah mampu meningkatkan konsentrasi amiloid pada bagian korteks otak tikus yang diberikan diet sampai berusia 13 bulan.

\section{KESIMPULAN}

Pemberian minyak ikan lele cenderung menekan bobot badan tikus yang di intervensi oleh pakan hiperkolesterolemia. Pemberian minyak ikan lele secara tunggal atau dikombinasikan dengan omega 3 atau omega 3 dan vitamin $\mathrm{E}$ dapat memengaruhi perubahan sel pada preparat jaringan hati dibandingkan dengan kontrol, namun tidak ada perbedaan antara perlakuan pemberian minyak ikan lele. Pemberian minyak ikan lele dan kombinasinya juga tidak memberikan perbedaan berarti dibanding kontrol pada preparat ginjal dan otak. Disarankan agar waktu intervensi pemberian minyak ikan lele pada tikus hiperkolesterolemia pada penelitian berikutnya diberikan dalam waktu lebih lama minimal sembilan bulan. Hal ini diharapkan dapat memberikan pengaruh terhadap perubahan sel pada preparat hati, ginjal, dan otak tikus yang nyata antar perlakuan.

\section{UCAPAN TERIMA KASIH}

Peneliti menyampaikan terimakasih kepada Kemenristekdikti yang telah mensponsori pendanaan penelitian ini melalui skim Penelitian Unggulan Perguruan Tinggi tahun anggaran 2015.

\section{DAFTAR PUSTAKA}

Alzheimer's Association. 2017. Alzheimer's Association Report: 2017 Alzheimer's disease facts and figures. Alzheimer's \& Dementia:1-50. http://dx.doi.org/10.1016/j. jalz.2017.02.001.

Arsenault D, Julien C, Chen CT, Bazinet RP, Calon F. 2012. Dietary intake of unsaturated fatty acid modulates physiological properties of ethorhinal cortex neurons in mice. Journal of Neurochemistry:1-17. https://doi. org/10.1111/j.1471-4159.2012.07772.x.

Astuti DA. 2015. Diet untuk hewan model. Bogor: IPB press.

Bhagaskara, Liana P, Santoso B. 2015. Hubungan kadar lipid dengan kadar ureum dan kreatinin pasien ginjal kronik di RSUP Dr. Mohammad Hoesin Palembang Periode 1 Januari-31 Desember 2013. Jurnal kedokteran dan kesehatan 2(2):223-230.

Chen LH, Wang YF, Xu QH, Chen SS. 2016. Omega-3 fatty acids as a treatment for nonalcoholic fatty liver disease in children: A systematic review and meta-analysis of randomized controlled trials. Clinical Nutrition:1-6. http://dx.doi.org/10.1016/j. clnu.2016.12.009. 
Chien MY, Ku YH, Chang JM, Yang CM, Chen CH. 2016. Effect of herbal mixture extracts on obesity in rats fed a high-fat diet. J Food Drug Anal 24(3):594-601.

Cooper JL. 2003. Dietary lipids in the aetiology of alzheimer's disease: implications for therapy. Drugs Aging 20(6):399-418.

Covington MB. 2004. Omega 3 fatty acid. Am Fam Physician 70(1):133-140.

Dainy NC, Kusharto CM, Madanijah S, Nasrun MWS. 2016. Catfish (Clarias gariepinus) biscuit and oil supplementation and its effect on lipid profile, oxidative stress markers and cognitive function of the elderly. IJBAR 28(3):181-194.

Davidson EP, Coppey LJ, Calcut NA, Oltman CL, Yorek MA. 2010. Diet induced obesity in Sprague Dawley rat causes microvascular and neural dysfunction. Diabetes Metab Res Rev 26(4):306-318.

Freeman LR, Granholm ACE. 2012. Vascular change in rat hippocampus following a high saturated fat and cholesterol diet. Journal of cerebral blood flow and metabolism 32(4):643-653. https://doi.org/10.1038/ jcbfm. 2011.168

Gonzales S, Huerta JM, Fernandez S, Patterson AM, Lasheras C. 2010. The relationship between dietary lipids and cognitive performance in an eldery population. Int $\mathrm{J}$ Food Sci Nutr 61(2):217-225. https://doi. org/10.3109/09637480903348098

Gani N, Momuat LI, Pitoi MM. 2013. Profil lipida plasma tikus wistar yang hiperkolesterolemia pada pemberian gedi merah (Abelmoschus manihot L.). Jurnal MIPA UNSTRAT online 2(1):44-49.

Granholm ACE, Bimonte-Nelson HA, Moore AB, Nelson ME, Freeman LR, Sambamurti K. 2008. Effects of a saturated fat and high cholesterol diet on memory and hippocampal morphology in the middle-aged rat. J Alzheimers Diseases 14(2):133-145.

Hardiningsih R, Nurhidayat N. 2006. Pengaruh pemberian pakan hiperkolesterolemia terhadap bobot badan tikus putih wistar yang diberi bakteri asam laktat. Biodiversitas 7(2):127-130.

Harini M, Okid DA. 2009. Blood Cholesterol Level of Hypercholesterolemia Rat (Rattus norvegicus) After VCO Treatment. J Biosci 1(2):53-58.

Hassanali Z, Ametaj BN, Field CJ, Proctor SD, Vine DF. 2010. Dietary supplementation of n-3 PUFA reduced weight gain and improves postpandrial lipaemia and the associated inflammatory response in the obese JCR:LA-cp rat. Diabetes, Obesity and
Metabolism 12(2):139-147. https://doi. org/10.1111/j.1463-1326.2009.01130.x

Herpandi. 2005. Aktivitas Hipokolesterolemik Tepung Rumput Laut Pada Tikus Hiperkolesterolemia. [Tesis]. Bogor: Institut Pertanian Bogor.

Ihedioha JI, Noel-Uneke OA, Ihedioha TE. 2013. Reference values for the serum lipid profile of albino rats (Rattus norvegicus) of varied ages and sexes. Comp Clin Pathol 22(1):93-99. https://doi.org/10.1007/ s00580-011-1372-7.

Irianto HE, Soesilo I. 2007. Dukungan Teknologi Penyediaan Produk Perikanan. Badan Riset Kelautan dan Perikanan. Departemen Kelautan dan Perikanan:1-20.

Julien C, Tremblay C, Phivilay A, Berthiaume L, Emond V, Julien P, Calon F. 2010. Highfat diet aggravates amyloid-beta and tau pathologies in the $3 \times \mathrm{Tg}$-AD mouse model. Neurology of Aging 31(9):1516-1531.

Kolorev IO. 2014. Alzheimer's disease: a clinical and basic science review. Med Student Res J 4:24-33.

Krisnansari D, Sulistyo H, Ati VRB. 2014. Efek propolis terhadap fungsi dan perlemakan hati tikus putih (Rattus norvegicus) model hhiperkolesterolemia. Penel Gizi Makan 37(1):77-85.

Kusharto CM, Madanijah S, Suseno SH. 2015. Minyak ikan lele (Clarias gariepinus) sebagai suplemen alternatif pencegah Alzheimer pada lansia [Laporan Penelitian]. Bogor (ID): Institut Pertanian Bogor.

Laksitoresmi DR, Kusharto CM, Sinaga T, Sulaeman A. 2016. Catfish (Clarias gariepinus) oil intervention and its effect on lipid profile and MDA levels of hypercholesterolemic male Sprague dawley rats. Journal of Biology, Agriculture and Healthcare 6(22):67-73.

Marques C, Meireles M, Norberto S, Leite J, Freitas J, Pestana D, Faria A, Calhau C. 2016. High-fat diet-induced obesity rat model: a comparison between Wistar and SpragueDawley rat. Adipocyte 5(1):11-21.

Mendez-Sanchez N, Gonzalez V, Aguayo P, Sanchez JM, Tanimoto MA, Elizando J, Uribe M. 2001. Fish oil (n-3) polyunsurated fatty acids beneficially affec biliary cholesterol nucleation time in obese women losing weight. J Nutr 131(9):2300-2303.

Minis R, Haq I, Jackson PR, Yeo W, Ramsay L. 2006. Oily fish and fish oil supplements in the prevention of coronary heart disease. $\mathrm{J}$ Hum Nutr Dietetics 5:449-459. https://doi. org/10.1046/j.1365-277X.1998.00074.x. 
Mona CLHF. 2014. Pengaruh diet minyak ikan terhadap waktu pembekuan darah pada tikus galur wistar jantan. [skripsi]. Fakultas Kedokteran Gigi. Universitas Negeri Jember.

Nikasa M, Karimi P, Rajavand H, Afshari F, Jafarlou M, Soltanali M. 2016. High cholesterol diet increase expression of cholesterol 24-hydroxylase and BACE1 in rat hippocampi: implications for the effect of diet cholesterol on memory. Iran Red Crescent Med J 18(12):1-8.

Noeman SA, Hamooda HE, Baalash A. 2011. Biochemical study of oxidative stress markers in the liver, kidney and heart of high fat diet induced obesity in rats. Diabetol Metab Syndr 3(1):1-17.

Nurdin MN, Rimbawan, Marliyati SA. 2016. Akumulasi lipid hati dan profil lipid darah tikus Sprague dawley yang diintervensi minyak super olein dan olein. J Gizi Pangan 11(1):67-74.

Phivilay A, Julien C, Tremblay C, Berthiaume L, Julien P, Giguere Y, Calon F. 2009. High dietary consumption of trans fatty acids decreases brain docosahexaenoic acid but does not alter amyloid- $\beta$ and tau pathologies in the 3xTG-AD model of alzheimer's disease. Neuroscience 159:296-307.

Reitz C, Brayne C, Mayeux R. 2011. Epidemiology of Alzheimer disease. Nat Rev Neurol 7(3):137-152. https://doi.org/10.1038/nrneurol.2011.2.

Ruzickova J, Rossmeisl M, Prazak T, Flachs P, Sponarova J, Vecka M, Tvrzicka E, Bryhn M, Kopecky J. 2004. Omega-3 PUFA of marine origin limit diet-induced obesity in mice by reducing cellularity of adipose tissue. Lipids 39(12):1177-1185.
Simopoulos AP. 2016. An increase in omega 6/ omega 3 fatty acid ratio increase the risk of obesity. Nutrients 8(128):1-17.

Srimiati M, Kusharto CM, Tanziha I, Suseno SH. 2015. Effect of different bleaching temperatures on the quality of catfish (Clarias gariepinus) oil. Procedia Food Science 3:223-230.

Wei Z, Wang W, Chen J, Yang D, Yan R, Cai Q. 2014. A prospective, randomized, controlled study of omega-3 fish oil fat emulsion-based parenteral nutrition for patients following surgical resection of gastric tumors. Nutrition Journal 13:25-36.

Wood JT, Williams JS, Pandarinathan L, Janero DR, Lammi-Keefe CJ, Makriyannis A. 2010. Dietary docosahexaenoic acid supplementation alters select physiological endocannabinoid-system metabolites in brain and plasma. J Lipid Res 51(6):1416-1423. https://doi.org/10.1194/jlr.M002436

Wresdiyati T, Hartanta AB, Astawan M. 2015. Tepung rumput laut (Eucheuma cottonii) menaikkan level superoksida dismutase (SoD) ginjal tikus hiperkolesterolemia. Jumal Veteriner 12(2): 126-135.

Wresdiyati T, Karmila A, Astawan M, Karnila R. 2015. Teripang pasir meningkatkan kandungan antoksidan superoksida dismutase pada pancreas tikus diabetes. Jurnal Veteriner 16(1):145-151.

Zarafoza C, Gomez-Guerrero C, Martin-Ventura JL, Blanco-Colio L, Lavin B, Mallvia $B$, Tarin $C$, Mas S, Ortiz A, Egido J. 2011. Animal model of cardiovascular disease. Journal of Biomedicine and Biotechnology 497841:1-13. http://dx.doi. org/10.1155/2011/497841. 